\title{
Surface hardness of hybrid ionomer cement after immersion in antiseptic solution
}

\author{
Anita Yuliati and Ajeng Kartika Sri Wardani \\ Department of Dental Material \\ Faculty of Dentistry Airlangga University \\ Surabaya - Indonesia
}

\begin{abstract}
Hybrid ionomer cement or resin modified glass ionomer cement is a developed form of conventional glass ionomer cement. This hybrid ionomer cement can be eroded if in direct contact with acid solution which will affect surface hardness. The aim of this study is to learn surface hardness of hybrid ionomer cement after immersion in methyl salicylate $0.06 \%$ (pH 3.6) and povidon iodine $1 \%$ ( $p H$ 2.9) solution. Sample of hybrid ionomer cement with $5 \mathrm{~mm}$ diameter and $3 \mathrm{~mm}$ thickness was immersed in sterile aquadest solution (control), methyl salicylate pH 3.6, povidon iodine $\mathrm{pH} 2.9$ for 1 minute, 7 and 14 minutes. Surface hardness was measured with Micro Vickers Hardness Tester. The obtained data was analyzed statistically with ANOVA followed by LSD test. The result of hybrid ionomer cement after immersion in sterile aquadest, methyl salicylate $0.06 \% \mathrm{pH} 3.6$ and povidon iodine $1 \% \mathrm{pH} 2.9$ for one minute, showed no significant difference; while immersion for 7 and 14 minutes showed a significant difference. The conclusion states that hybrid ionomer cement after 14 minutes immersion in povidon iodine $1 \%$ pH 2.9 has the lowest surface hardness.
\end{abstract}

Key words: hybrid ionomer cement, antiseptic solution, surface hardness

Correspondence: Anita Yuliati, c/o: Bagian Ilmu Material dan Teknologi Kedokteran Gigi, Fakultas Kedokteran Gigi Universitas Airlangga. Jln. Mayjend. Prof. Dr. Moestopo No. 47 Surabaya 60132, Indonesia.

\section{INTRODUCTION}

Conventional glass ionomer cement has been used for esthetic filling in cavity with low stress bearing, for example in class III and IV restoration, in patient with high caries risk, or on pit and fissure. The most common problem found in conventional glass ionomer cement is its sensitivity to moisture and its low initial strength. In the early 1990, modified resin glass ionomer cement was released into market to produce good physical nature similar to those of composite resin, and still it could maintain the basic features of the conventional glass ionomer cement. These new material was called as resin modified glass ionomer cements or hybrid ionomers. ${ }^{1,2}$

The composition of hybrid ionomer cement is similar with conventional glass ionomer cement. Hybrid ionomer cement contains polyacrilyc acid or modified polyacrilyc acid with monomer hydroxyethyl methacrylate (HEMA) or Bis-GMA in the liquid. ${ }^{3}$ Hybrid ionomer cement has better qualities than conventional ionomer cement in: controllable working time, less sensitivity to moisture, wear resistance solubility, low, good esthetics, fluoride release, biocompatibility, adhesion to a moist tooth structure, more elastic, good dimentional stability, and higher surface hardness. ${ }^{1,4,5}$ Based on in vitro analysis, hybrid ionomer cement releases fluoride in equal amount with what is released by conventional glass ionomer. ${ }^{6}$

At present, people tend to keep the hygiene of their mouth cavity using mouthwash as an antiseptic liquid to maintain oral health, although they have brushed their teeth regularly. Antiseptic is a chemical agent utilized on mucosa surface or skin to kill microorganism by destroying or inhibiting microorganism growth. ${ }^{7}$

Preliminary survey by researcher had found brand of antiseptic solution commonly used and circulated in the market was antiseptic liquid containing methyl salicylate $0.06 \%$ and povidon iodine $1 \%$. pH of methyl salicylate $0.06 \%$ was 3.6 and povidon iodine $1 \%$ had $\mathrm{pH} 2.9$. Manufacturer's formula has indicated that the antiseptic solution can reduce foul breath, eliminate plaque and decrease oral ulceration. It is recommended to gargle 30 seconds twice/day, maximal in 14 days. Hybrid ionomer cement will contact directly with antiseptic solution in oral cavity, where the antiseptic solution is acid in nature. Hybrid ionomer cement can undergo erotion if in contact with acid solution and it affects surface hardness. ${ }^{8}$

This study used a conversion of antiseptic solution against hybrid ionomer cement, as follows: hybrid ionomer in contact with antiseptic solution in 1 minute (duration of antiseptic solution for 1 day), 7 minutes ( 7 days duration of antiseptic solution usage) and 14 minutes ( 2 weeks duration).Therefore, problems rise in pertaining to surface hardness of hybrid ionomer cement after immersion in acidic antiseptic solution.

The purpose of this study is to learn surface hardness of hybrid ionomer cement after immersion in methyl salicylate $0.06 \%(\mathrm{pH} 3.6)$ and povidon iodine $1 \%(\mathrm{pH} 2.9)$ solution for 1,7 and 14 minutes. The benefit of this study 
is to understand the effect of acidic antiseptic solution usage inside mouthwash liquids towards hybrid ionomer surface, so that erotion process can be prevented.

\section{MATERIALS AND METHODS}

This is an experimental laboratory study. Carried out in Material and Technology Department, School of Dentistry, Airlangga University and Laboratory of Technical Engineering, Institute of Sepuluh Nopember, Surabaya.

The materials used are: type II hybrid ionomer cement (Fuji II LC, GC Corporation, Tokyo, Japan, Reorder No. 000225); methyl salicylate $0.06 \%$ (Listerine, PT. Bayer Indonesia, Reg.POM CD 1302101501); and povidon iodine 1\% (Isodine, PT. Mahakam Beta Farma, Depkes RI.BPD.05100021). The tools are: cylindric Teflon $5 \times 3 \mathrm{~mm},{ }^{9}$ plastic spatula, glass slab, $1 \mathrm{~kg}$ weight scale, magnifier glass, celluloid strip, striped visible light unit (Litex) and Micro Vickers Hardness Tester (Shimadzu).

The sample of hybrid ionomer cement was made as follows: the lower side of sample cast was given celluloid strips and put on top of glass slab. According to manufacturer's formula, hybrid ionomer cement and powder was mixed and put into plastic ring until the sample cast was full. Further procedure was performed following previous researchers. ${ }^{9}$ The samples were clustered based on treatments and sample number in every treatment cluster was 6.

The samples were treated like this, group I were immersed in aquadest sterile, group II were immersed in methyl salicylate $0.06 \%$ pH 3.6 and group III were soaked in povidon iodine $1 \% \mathrm{pH} 2.9$. Every treatment group were immersed for 1 minute, 7 and 14 minutes.

To measure sample surface hardness, the surface of sample which was already immersed was dried with tissue paper and marked with black marker pen. Then, the sample was placed in the middle of Micro Vicker Hardness Tester platform with 250 gram weight load. The picture in the lens was focused with 200 times enlargement, pressed red button, the diamond penetrator rised. The lens was changed with 400 times enlargement, then the result of sample surface penetration was seen in rhombus shaped cut. The result of diagonal length measurement was placed in a formula in Micro Vicker Hardness Tester manual i.e.

$$
\begin{aligned}
& \mathrm{V}=\frac{(1.854 \times \mathrm{P})}{\mathrm{d}^{2}} \\
& \mathrm{~V}=\operatorname{surface} \text { hardness }\left(\mathrm{Kg} / \mathrm{mm}^{2}\right) \\
& \mathrm{P}=\text { load }(\mathrm{Kg}) \\
& \mathrm{d}=\text { average diagonal length }(1 / 1000 \mathrm{~mm})
\end{aligned}
$$

Measurement was done in three different sites, averaged and the result of the average (mean) was taken as sample surface hardness.

\section{RESULTS}

Mean (average) and standard deviation of hybrid ionomer cement surface hardness after immersion in sterile aquadest, methyl salicylate $0.06 \% \mathrm{pH} 3.6$, povidon iodine $1 \%$ pH 2.9 in 1 minute, 7 and 14 minutes $\left(\mathrm{Kg} / \mathrm{mm}^{2}\right)$ were presented in table 1.

Table 1 showed that hybrid ionomer cement after immersion in povidon iodine antiseptic solution $1 \% \mathrm{pH} 2.9$ had the lowest surface hardness compared with the two other groups. Data inside table 1 was homogen, normal distribution, tested with One Sample KolmogorovSmirnov Test. Furthermore, it was analyzed with One-Way ANOVA Test, and $p<0.05$. This result showed that there was a significant difference of surface hardness after immersion in sterile aquadest and antiseptic solution with different $\mathrm{pH}$. The different treatment was tested with LSD as seen in Table 2.

Hybrid ionomer cement after immersion in methyl salicylate $0.06 \% \mathrm{pH} 3.6$ and povidon iodine $1 \% \mathrm{pH} 2.9$ for 1 minute showed no significant difference, it meant there was no surface hardness decrease. While after immersion for $e^{\bullet} 7$ minutes, there was a significant difference, meaning there was a decrease of surface hardness.

\section{DISCUSSION}

Another vehicle for delivering active agents with desirable effects to the surfaces of the teeth and gingival is mouthwash. This liquid is a commonly used antiseptic solution to enhance oral hygiene, esthetic and breath

Table 1. Mean and standard deviation of hybrid ionomer cement surface hardness after immersion in sterile aquadest, methyl salicylate $0.06 \% \mathrm{pH} 3.6$, povidon iodine $1 \% \mathrm{pH} 2.9$ in 1,7 and 14 minutes $\left(\mathrm{Kg} / \mathrm{mm}^{2}\right)$

\begin{tabular}{ccccc}
\hline \multirow{2}{*}{$\begin{array}{c}\text { Duration of } \\
\text { immersion }\end{array}$} & $\mathrm{n}$ & $\begin{array}{c}\text { Sterile aquadest } \\
\text { (control) }\end{array}$ & $\begin{array}{c}\text { Methyl salicylate 0.06\% } \\
\mathrm{pH} 3.6\end{array}$ & $\begin{array}{c}\text { Povidon iodine 1\% } \\
\mathrm{pH} 2.9\end{array}$ \\
\cline { 3 - 5 } & & $\mathrm{X} \pm \mathrm{SD}$ & $\overline{\mathrm{X}} \pm \mathrm{SD}$ & $\overline{\mathrm{X}} \pm \mathrm{SD}$ \\
\hline 1 minute & 6 & $41.29 \pm 0.77$ & $41.06 \pm 1.04$ & $40.95 \pm 1.17$ \\
7 minutes & 6 & $38.19 \pm 0.56$ & $38.15 \pm 0.92$ & $37.11 \pm 1.09$ \\
14 minutes & 6 & $39.13 \pm 1.03$ & $35.17 \pm 0.43$ & $32.85 \pm 1.61$ \\
\hline
\end{tabular}


Table 2. LSD test of hybrid ionomer cement surface hardness after immersion in aquadest and antiseptic solution with different $\mathrm{pH}$

\begin{tabular}{cccccccccc}
\hline Immersion & \multicolumn{3}{c}{ Sterile aquadest $\mathrm{pH} 7$ (control) } & \multicolumn{2}{c}{ Methyl salicylate $0.06 \% \mathrm{pH} 3.6$} & \multicolumn{3}{c}{ Povidon iodine $1 \% \mathrm{pH} 2.9$} \\
\cline { 2 - 9 } duration & $1 \mathrm{mnt}$ & $7 \mathrm{mnt}$ & $14 \mathrm{mnt}$ & $1 \mathrm{mnt}$ & $7 \mathrm{mnt}$ & $14 \mathrm{mnt}$ & $1 \mathrm{mnt}$ & $7 \mathrm{mnt}$ & $14 \mathrm{mnt}$ \\
\hline 1 minute & - & $\mathrm{S}$ & $\mathrm{S}$ & $\mathrm{NS}$ & $\mathrm{S}$ & $\mathrm{S}$ & $\mathrm{NS}$ & $\mathrm{S}$ & $\mathrm{S}$ \\
7 minutes & & - & $\mathrm{S}$ & $\mathrm{S}$ & $\mathrm{S}$ & $\mathrm{S}$ & $\mathrm{S}$ & $\mathrm{S}$ & $\mathrm{S}$ \\
14 minutes & & & - & $\mathrm{S}$ & $\mathrm{S}$ & $\mathrm{S}$ & $\mathrm{S}$ & $\mathrm{S}$ & $\mathrm{S}$ \\
\hline
\end{tabular}

Note: $\mathrm{S}$ = significant; $\mathrm{NS}=$ non-significant

freshnness. Two natures of antiseptic solution which has to be watched is the acid and ethanol content. These two natures are very damaging to composite resin, compomer and sealant restoration materials. ${ }^{1}$ Thus, the usage of mouthwash can affect physical and mechanical natures of dental restoration materials.

The result of this study showed that the longer hybrid ionomer cement immersed in sterile aquadest, methyl salicylate $0.06 \% \mathrm{pH} 3.6$ and povidon iodine $1 \% \mathrm{ph} 2.9$ solutions, the more surface hardness decreased. Hybrid ionomer cement surface hardness is easily affected by storage media. 5 Other researchers stated that the longer hybrid ionomer cement immersed in pure water, the more water can be absorbed, so that surface hardness becomes softer. Physical nature of hybrid ionomer after being soaked in water will be softer. Water will be absorbed by HEMA inside hybrid ionomer cement because of HEMA's hydrophilic character. Water absorption will inhibit metal ion cross ties because metal ion will be dissolved in water. Metal ion which was detached from hydroxyl compound inside hybrid ionomer cement will cause the material to be fragile. ${ }^{10}$ hybrid ionomer cement will absorb the liquid which will dissolve matrix forming cation and anion to surrounding areas. This happening will produce fragile cement dissolved easily, causing transparent significant alteration. ${ }^{6}$

Antiseptic solution used as mouthwash has composed of three main ingredients, namely active agents, surfactants, and flavoring agents. Methyl salicylate $0.06 \%$ inside mouthwash is a flavoring agent functioning as breath freshnness. Active agents inside mouthwash can be liquefied in water and/or alcohol. ${ }^{1}$ Active agents inside antiseptic solution used in this study is dissolved in alcohol. It is written outside the packaging of these two antiseptic solutions that it has high alcohol level (ethanol 21.6\%) for methyl salicylate, whereas povidon iodine has not shown any alcohol percentage.

Alcohol inside gargle liquid antiseptic solution can influence surface hardness. This study has proven that the longer hybrid ionomer cement immersion in methyl salicylate $0.06 \% \mathrm{pH} 3.6$ and povidon iodine $1 \%$, the weaker hybrid ionomer cement surface will be. Thus, a significant decrease of surface hardness is persistent. Ionomer cement is sensitive towards acid. Acid media causing erosion is saliva, plaque and alcoholic beverages. Hardened glass ionomer cement consisted of glass particle clumps which did not react and covered by silica gel. Unreacted particle clumps are covered by silica gel in amorphous matrix of calcium hydrate and aluminum salt mixture. ${ }^{6}$ Alcohol inside antiseptic solution can dissolve part of hybrid ionomer cement matrix, causing damage at hybrid ionomer cement structure and decreased surface hardness.

Hybrid ionomer cement immersed in povidon iodine $1 \% \mathrm{pH} 2.9$ has the lowest surface hardness compared to other groups. The decreasing surface hardness is caused by erosion due to direct contact with acid, in particular strong acid. In acidic milieu, ionomer cement matrix will be dissolved, physical and mechanical nature will also decrease. This can cause detachment of metal ion inside hybrid ionomer. ${ }^{8}$ The result of this study is in accordance with hypothesis that glass ionomer cement surface hardness (Fuji LC II) can decrease along with the decrease of $\mathrm{pH}$ and time. Observation with electron microscope shows that after 5 hours of immersion in citric acid added with artificial saliva $\mathrm{pH} 3$, the microstructure of hybrid ionomer cement does change. The surface splits, more porous and after 72 hours immersion, surface texture lessen. ${ }^{5}$

Erosion mechanism can be illustrated as follows: $\mathrm{H}^{+}$ ion solution enters inside cement and change place with metal cation in polycarboxilate molecule cross ties inside cement matrix. ${ }^{9}$ Hybrid ionomer cement solution containing HEMA in acidic milieu will cause excess hydrogen ion $\left(\mathrm{H}^{+}\right)$. This will replace metal ion which has cross tied with polyalkenoat chain, causing breakage of cement matrix ties. This is the beginning of degradation process for dissolving material.

Erosion and hybrid ionomer cement dissolvement has been declared by other researcher, also that hybrid ionomer cement can dissolve, releasing substances during immersion in distilled water, but when tested with lactic acid, only small portion dissolve in erosion test. It is further said that basically resin cement is not easily dissolved, only releasing small amount of substances i.e. unreacted monomer. Unreacted monomer will definitely weaken ionomer resin cement surface hardness. ${ }^{12}$

Conclusion of this study reveals that hybrid ionomer cement immersion for 14 minutes in povidon iodine $1 \%$ pH 2.9 has the lowest surface hardness.

\section{REFERENCES}

1. Craig RG, Powers JM. Restorative dental material. $11^{\text {th }}$ ed. St Louis, London, Philadelphia, Sydney, Toronto: Mosby A Harcourt Health Sciences Company; 2002. p. 203-5, 614-8. 
2. Nagaraja UP, Kishore G. Glass ionomer cement-the different generations. Trends Biomater Artif Organs 2005; 18(2): 158-65.

3. Hatrick CD, Eakle WS, Bird WF. Dental materials. Clinical applications for dental assistants and dental hygienists. Philadelphia, London, New York, St Louis, Sydney, Toronto: Saunders; 2003. p. 183.

4. Hara AT, Serra MC, Rodrigues AL. Radiopacity of glass-ionomer/ composite resin hybrid materials. Braz Dent J 2001; 12(2): 85-9.

5. Koppari S, Persson M. The effect of storage in different $\mathrm{pH}$ on the surface microhadness of a resin-modified glass ionomer cement and resin composite. Department of Dental Biomaterials science. Karolinska Institutet Huddinge, Sweden. 2005. 427-38. Available at www.ki.se/odont/caridogi_endodonti/kov/Tio Stina_koppari_Maria_persson.PDF. Accessed April 30, 2005.

6. Anusavice KJ. Phillips science of dental material. $11^{\text {th }}$ ed. USA: Elsevier Science; 2003. p. 358-61, 471-8.
7. Samaranayake LP. Essential microbiology for dentistry. Edinburgh London, New York, Philadelphia, St Louis, Sydney, Toronto: Churchill Livingstone; 2002. p. 262.

8. Fukazawa M, Matsuya S, Yamane M. The mechanism for erosion of glass-ionomer cement in organic-acid buffer solutions. J Dent Res 1990; 69(5): 1175-9.

9. Farihah SH, Meizarini A, Yuliati A. Variasi ketebalan celluloid strip terhadap kekerasan permukaan resin komposit sinar tampak. Majalah Kedokteran Gigi (Dent J) 2001; 34(4): 753-5.

10. Nicholas JW, Antice HN, McLean JW. A preliminary report on the effect of storage in water on properties of commercial light cured glass ionomer cements. Br Dent J 1992; 151: 98-101.

11. Mc Cabe JF, Walls AWG. Applied dental materials. $8^{\text {th }}$ ed. Blackwell Science; 2000. p. 212-7.

12. Jones DW. Dental cements: A further update. J Can Dent Assoc 1998; 64: 788-9. 